\section{Jurnal Hukum Volkgeist \\ Volume 5 Issue 2, 2021 \\ P-ISSN : 2528-360X, E-ISSN : 2621-6159}

HUKUV

Mimbar Pendidikan Hukum Nasional

\title{
The Institutional Form of Policyholder Protection Scheme in Indonesia (A Comparison Study Between Indonesia, Malaysia, and South Korea)
}

\author{
Putri Nurul Hidayati ${ }^{1}$
}

\begin{abstract}
This study is about the urgency of establishing a Policyholder Protection Fund for policyholders and insurance companies in Indonesia. The discussion in this study includes the urgency of establishing a Policyholder Protection Fund in Indonesia, the comparison study between Indonesia, Malaysia and South Ko re a Policyholder Protection Funds that can be applied in Indonesia. The research method used is a normative juridical research method. The author concludes that the Policyholder Protection Fund in Indonesia should immediately be established. This is because many insurance companies have failed to pay and the Policyholder Protection Fund can provide benefits to policyholders in the form of legal protection. The Policyholder Protection Fund can also provide benefits to the economic system in general. Also, the form of the policyholder guarantee program that can be applied in Indonesia is as an independent institution that is separate from the Deposit Insurance Corporation.
\end{abstract}

Keywords: Policy Guarantee Program, Policy Guarantee Agency, Deposit Insurance Corporation, Insurance Company, Policy Holder.

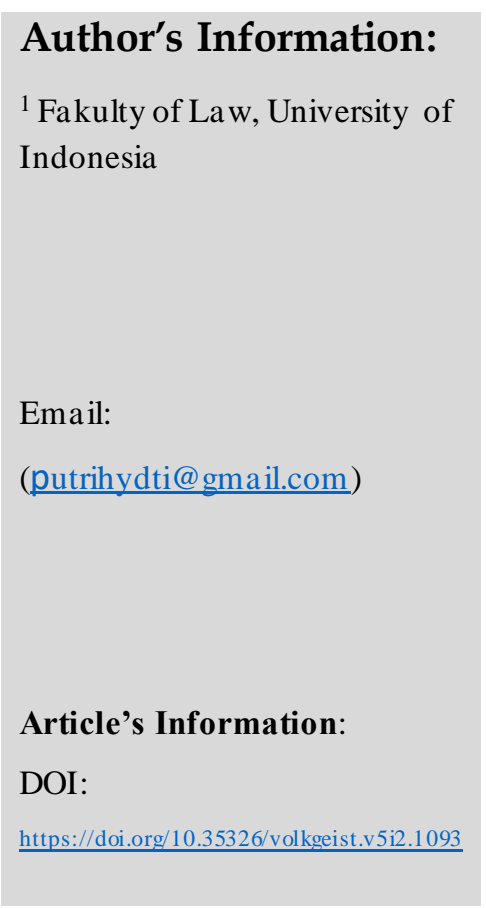

\section{Introduction}

The ultimate goal of a policy in a country is to achieve the welfare of the people, and the state has the responsibility to protect the nation and advance the general welfare (A Junaedy Ganie, 2013, p.23). Article 53 of Act No. 43 of 2014 regarding Insurance (Insurance Law) states that the implementation of policyholder protection schemes is regulated by the law. Law regarding the implementation of policyholder protection scheme as referred in Article 53 of Insurance Law should be established no later than 3 (three) years since the enactment of the law. Law Insurance was enacted on October 17, 2014, so the law regarding the implementation of the policyholder protection scheme should have been established no later than October 17, 2017. However, until this time, the law has not been formed.

Article 53 of Insurance Law does not explicitly regulate the institution form of policyholder protection scheme. However, recently there is a discourse to establish the institution as an independent institution or an institution merged with DIC. Related to the discourse of policyholder protection scheme in the form of an independent institution through Policy Insurance Corporation (hereinafter referred to LPP) is as delivered by Financial Service Authority (hereinafter referred to OJK). As mandated by Insurance Law related to the establishment of the policyholder protection scheme, OJK, 
as a regulator, is currently coordinated with the government to establish the policyholder protection scheme through LPP. OJK also has submitted the files to the government as a consideration for the establishment of LPP. Based on the OJK statement, LPP is an independent institution and is not integrated with the Deposit Insurance Corporation (hereinafter referred to DIC) (HukumOnline, 2017).

Meanwhile, related to the discourse of LPP merging with DIC, DIC stated that they are ready to hold concurrent duties if later they get an assignment to be an LPP. Currently, the establishment of the institution is being prepared by the government through the Ministry of Finance. Nevertheless, DIC stated that the existence of legal protection is needed (CNN Indonesia, 2020). The Chairman of the Board of Commissioners, Halim Alamsyah, stated that until this time, DIC functions as the deposit insurance according to the regulation applied. However, it does not rule out the possibility if, in the future, the government and House of Representatives decide to merge the policy insurance to DIC (Monica Wareza, CNBC Indonesia, 2020).

The institutional form of policyholder protection schemes in other countries is actually also diverse. There are countries with LPP as an independent institution, and there are countries with a policyholder protection scheme that is integrated with DIC in the countries. In this study, the discussion will be focused on the countries with a policyholder protection scheme that is integrated with DIC. The countries intended are Malaysia and South Korea. The analysis of the study includes the position of policyholder protection scheme in the laws and regulations of Indonesia and the analysis related to the expansion of the DIC function as the policy insurance by comparing the provisions of Malaysia and South Korea.

\section{Methodology}

In doing research, the writer uses the doctrinal research method, which is research that provides systematic exposure to regulations that govern certain legal categories, analyzes the relationship between regulations, explains areas that experience obstacles, and even predicts future developments. Normative law research uses normative legal case studies in the form of products of legal behavior, for example reviewing draft laws. The subject of the study is the law which is conceptualized as a norm or rule that applies in society and becomes a reference for everyone's behavior. So that normative legal research focuses on an inventory of positive law, legal principles and doctrines, legal findings in cases in concreto, legal systems, legal synchronization levels, legal comparisons, and legal history (Abdulkadir. 2004, h. 52).

Sources of legal materials used in this study include primary legal materials, secondary legal materials, and tertiary legal materials. Primary legal materials include laws and regulations. Secondary legal materials include related literature in the form of books, scientific journals, articles in news, and articles on the internet. As well as tertiary legal materials which include legal dictionaries.

This study uses a qualitative approach, namely analyzing and processing data based on the researcher's understanding of the data or information obtained which is then narrated to obtain research conclusions. Qualitative methods put more emphasis on observing phenomena and examining the substance of the meaning of these phenomena. The analysis and sharpness of qualitative research greatly affect the strength of the words and sentences used. Therefore, Basri (2014) concludes that the focus of qualitative research is on the process and the meaning of the results. Qualitative 
research attention is more focused on human elements, objects, and institutions, as well as the relationship or interaction between these elements, in an effort to understand an event, behavior, or phenomenon (Mohamed. 2010).

\section{Result and Discussion}

\subsection{The Position of policyholder protection scheme in the Laws and Regulations of Indonesia}

The legal basis related to the policyholder protection scheme is regulated in Article 53 of Insurance law (Negara Kesatuan Republik Indonesia, 2014) . Article 53 paragraph (1) of Insurance Law stated that the insurance companies are required to be a participant of policyholder protection scheme. The provisions of Article 53 paragraph (3) of Insurance Law regulated that when the policyholder protection scheme is valid based on the law, then the provisions regarding the guarantee fund are stated as invalid for the insurance companies and the sharia insurance companies. Article 53 paragraph (4) of Insurance Law regulates that regulation concerning policyholder protection scheme is formed no later than 3 years since the enactment of Insurance Law.

Based on the provisions of Article 20 paragraph (3) of Insurance Law (Negara Kesatuan Republik Indonesia, 2014), because until this time, due to the absence of a policyholder protection scheme, the provisions regarding the guarantee fund apply. The definition of a guarantee fund based on the provisions in Article 1 No. 19 is the wealth of insurance companies, shariah insurance companies, reinsurance companies, or shariah reinsurance companies. The guarantee fund has function as the final guarantee to protect the interests of the policyholder, the insured, or the participant in the case that insurance companies, shariah insurance companies, reinsurance companies, and shariah reinsurance companies are liquidated.

The guarantee fund is one of the criteria or requirements for the insurance companies to get business licenses. This is as regulated in Article 8 paragraph (2) of Insurance Law (Negara Kesatuan Republik Indonesia, 2014). Article 20 paragraph (1) of Insurance Law also regulated the obligation of Insurance Companies, Sharia Insurance Companies, Reinsurance Companies, and Shariah Reinsurance Companies to form the guarantee fund. According to the provisions of Article 20, paragraph (2) of Insurance Law, the amount of the guarantee fund must be adjusted along with the business development of an insurance company. Based on the provisions of Article 20 paragraph (3) of Insurance Law, the guarantee fund cannot be collateralized or encumbered with any rights.

The explanation of Article 20 of Insurance Law states that the aim of establishing a guarantee fund is to provide a guarantee for the replacement of part or all of the rights of the policyholder, the insured, or participant in the case that company must be liquidated. Therefore, the guarantee fund is an effort to provide protection to the policyholder or the insured. The provisions regarding the guarantee fund are also intended so that the guarantee fund can return part or all of the rights of the policyholder, the insured, or the participant when the company is liquidated can be ascertained.

In line with the explanation of Article 20, which states the benefits of the Guarantee Fund for the policyholder, insured, or participants, the Indonesian Life Insurance Association (AAJI) stated the benefits of the policyholder protection scheme 
if it is formed. AAJI expects that by the policyholder protection scheme, the community increasingly trusts the insurance company and also obtain certainty about policy as DIC guarantees bank customer deposits (Hukum Online, 2017).

The objectives of establishing a policyholder protection scheme or policy insurance corporation are as follows:

a. Giving the legal protection for the policyholder or insured

Legal protection is basically protection for human rights harmed by other people, and the protection is given to the community so that they can enjoy all the rights provided by the law. Of course in this protection also think about the principle of dispute resolution, it is important to determine the choice of forum (choice of forum) (Salam, 2017). In the form of court institutions, arbitration institutions, or alternative dispute resolution institutions that are authorized for settlement. Legal protection can also be defined as all legal efforts that must be carried out by the law enforcement officers to the community to create a sense of security, either physically or mentally, from distractions and various threats from any party (Rahardjo, 1993).

Basically, the protection of policyholder or insurance insured already exists in the Indonesian laws and regulations, such as in the Civil Code (KUHPerdata) and Commercial Code (KUHD). The provisions in Civil Code related to the protection for the policyholder or insurance insured are referred to Article 1321 to Article 1329 of the (Negara Kesatuan Republik Indonesia, n.d.). In which the policyholder who feels that the insurance agreement contains error, coercion, and deception from the insurer, then he/she can submit the request for the cancellation of the insurance agreement to the court (Man Suparman, 2013, p. 10). Furthermore, the protection toward the policyholder or insured is also reflected in the provisions of Article 1267 of the Civil Code. If the insurer is obliged to provide compensation in accordance with the provisions agreed by each party, but the insurer evidently has the defaults, the insured can claim compensation and interests. Furthermore, the protection toward the policyholder or insured is also reflected in Commercial Code. Article 245 of the Commercial Code, which prohibits the parties in the insurance agreement, states to release things that are required by the provisions of law to be implemented or the things that have been strictly prohibited.

However, the existence of a policy insurance corporation is also needed to protect the interests of policyholders, especially the individual or non-professional policyholders, if the insurance company goes bankrupt. The fund is expected to function as the ultimate safety net for the policyholder when bankrupt occurs, despite all possible surveillance measures.

b. Increasing the public trust in the insurance industries

The insurance industry is established on public trust in insurance companies, in which this is vulnerable. A policyholder protection scheme can help maintain public trust in the insurance business and, therefore, help maintain health industry development.

As mentioned before, insurance has a specific quality of trust. Mutual trust between the parties who have a big role in holding the agreement. (Man Suparman, 2012, p.9): "Verzekering heeft een bijzander vertrouwens karakter, het onderling vetrouwen tussen de partijen speelt een grote rol"

c. The development of a competitive market 
The establishment of a policyholder protection scheme or LPP can contribute to the development of a competitive market. The policyholder protection scheme can support the dynamics in the development of a competitive market (Takahiro Yasui, 2001).

\subsection{The Expansion of the Function of Deposit Insurance Corporation as the Policy Insurance}

The House of Representatives of the Republic of Indonesia (DPR RI) states that currently, the Government is preparing the design for the establishment of LPP through the Policy Insurance Bill. The Bill includes into National Legislation Program (Prolegnas) 2020-2024. The background that underlies the drafting of the Policy Insurance Bill is to carry out the provisions of Insurances Law and is based on the condition of financial problems faced by the insurance companies, such as Jiwasraya and AJB Bumiputera. The DPR RI also stated that currently, the Government needs to carefully consider the appropriate institutional form for the policyholder protection scheme. As part of DIC or independent institution. This is because the decision regarding the institutional form of policyholder protection scheme will also have implications for the requirements of substantial funding for Human Resources, operational, and the initial capital of the insurance.

1. Regulations Regarding Deposit Insurance Corporation (DIC). As previously mentioned that there is a discourse to expand the function of DIC as LPP. Here are the legal bases and regulations regarding DIC in Indonesia:

a. Act No. 9 of 2019 regarding the Financial System Crisis Prevention and Management (Negara Kesatuan Republik Indonesia, 2016), Article 1, number 11 of Act No. 9 of 2016 elaborates the definition of DIC, in which DIC is an institution as referred to in the law regarding DIC.

b. Act No. 21 of 2011 regarding Financial Service Authority (Law Of Malaysia Act, 2011) Similar to Act No. 9 of 2016, Act No. 21 of 2011 in Article 1 Number 14 also elaborates the definition of DIC, which is an institution as referred to in the law regarding DIC.

c. The Determination of Government Regulation in Lieu of Law No. 3 of 2008 concerning the Amendments to Act No. 24 of 2004 (Negara Kesatuan Republik Indonesia, 2008) regarding the Deposit Insurance Corporation into Law (DIC Law)

The law regarding DIC as referred in Act No. 9 (Negara Kesatuan Republik Indonesia, 2016) and Act No. 21 (Law Of Malaysia Act, 2011) are the Determination of Government Regulation in Lieu of Law No. 3 of 2008 concerning the Amendments to Act No. 24 of (Negara Kesatuan Republik Indonesia, 2008) regarding the Deposit Insurance Corporation into Law. Article 2 paragraph (1) of DIC Law becomes the basis for the establishment of DIC. Article 2 paragraph (2) and (3) of DIC Law explains that DIC is a legal entity and is the independent, transparent, and accountable institution in implementing the duties and authorities.

There are two functions of DIC as regulated in Article 4 of DIC Law. The two functions are (1) to guarantee the deposit from the depositors and; (2) actively participate in maintaining the stability of the banking system in accordance with the authorities. Article 5 paragraph (1) of DIC Law regulated that in implementing the functions related to the insurance of costumer deposit, DIC has the duties to formulate and determine the policies for implementing deposit insurance. 
Meanwhile, in implementing the functions in maintaining the stability of the banking system, according to the provisions as referred to Article 5 paragraph (1) DIC Law, DIC has the duties to formulate and determine the policies to actively participate in maintaining the stability of banking system, formulating, determining, and implementing the resolution policies of Failing Bank that do not have a systemic impact; and implementing the handling of Failing Bank with systemic impact.

\section{The Function of Deposit Insurance Corporation (DIC) as the Policy Insurance}

The function of DIC is a deposit insurer, and hence we need to discuss the definition of "deposit" itself and whether the policy includes in the "deposit" category. Article 1, number 1 of the Determination of Government Regulation in Lieu of Law No. 3 explains that the definition of the deposit is as regulated in the Law concerning Banking. Article 1, number 5 of Act No. 10 of regarding Banking (Banking Law) mentioned the definition of deposit. It is a fund entrusted by the public to the bank based on the deposit agreement in the form of the current account, deposits, certificates of deposit, savings, or other equivalent forms (Negara Kesatuan Republik Indonesia, 2008).

To answer whether the policy includes the definition of deposit, the definition of policy needs to be elaborated. Basically, every agreement certainly needs a document. Policy as a deed, in which its formality is regulated in law, has an important meaning for an insurance agreement. Either at the initial stage of the agreement, as long as the agreement is valid, and during the implementation of the agreement (Hartono, 1992). An insurance policy is an agreement made by the insurer, in which in this case is an insurance company and insured or policyholder. The definition of Insurance Policy in Article 255 of the Commercial Code is mentioned that an insurance policy must be made in writing in a deed called policy. The policy is written evidence for the insurance agreement. The policy is also regulated in Article 256 of the Commercial Code. Ketut Sendra defined policy as agreement evidence and contains various agreements along with the boundaries or exclusions and the agreed benefits (Sendra, 2009). Ali, (1993) defined an insurance policy as a document containing a contract between the insured party and its insurance company. The insurance policy states the rights and obligations of the parties who made the contract. Briefly, an insurance policy is a document containing a contract between the insurance company and the insured party, in which the insurance policy states the rights and obligations of the parties who made the contract (Sumarni \& Tayib, 2019).

Thus, it can be concluded that policy includes in the definition of "Deposit" as referred to in Banking Law and the Determination of Government Regulation in Lieu of Law No. 3 of 2008. Due to the Banking Law mandates that policyholder protection scheme must be regulated by the law while the policy insurance is not the authority of DIC, then if later DIC is required to expand their authorities as to the policy insurance corporation, there must be a revision of DIC Law, which then becomes the legal protection for expanding its authority.

\section{The Merger of DIC and LPP in Malaysia and South Korea}

\section{a. Malaysia Deposit Insurance Corporation (PIDM)}

The merger of LPP and DIC also occurs in many other countries, such as Malaysia and South Korea. This merger is considered more efficient than establishing a new institution (Rossiana, 2014). The institution that merges the function of DIC as the policy insurance in Malaysia is the Malaysia Deposit Insurance Corporation (hereinafter 
referred to as PIDM). PIDM has the function to protect the deposit in the bank when there is a default in the bank and the benefit of takaful and insurance, the protection if there is a default in the insurance company (Perbadanan Insurans Deposit Malaysia, 2018).

Takaful is a participatory form of insurance based on risk sharing by customers on co-operative principles instead of risk transfer to a third party, the company. The customers participate in the technical and investment surplus of insurance and reinsurance funds (OECD, 2010). The establishment of the takaful insurance industry in Malaysia is due to the many needs of the Muslim community for Islamic alternatives to conventional insurance. It is also intended to complement the operation of the Islamic banking system in Malaysia. In 1984, the first takaful company was founded, Syarikat Takaful Malaysia (Norma, 2012).

PIDM is a Malaysian government institution established in 2005 under the Act regarding Malaysia Deposit Insurance Corporation (hereinafter referred to as PIDM Act). The legal basis for the establishment of PIDM is the Laws of Malaysia Act 642 Malaysia Deposit Insurance Corporation Act 2005. PIDM manages two financial consumer protection systems, Deposit Insurance System (DIS), to protect the bank depositors, and Tafakul \& Insurance Benefits Protection (TIPS) for the tafakul certificate and insurance policy owners. PDIM also provides the incentive for good risk management in the financial system, promotes and contributes to the stability of the Malaysian financial system (Perbadanan Insurans Deposit Malaysia, 2018).

Turn into the discussion regarding the policyholder protection scheme in Malaysia through TIPS. TIPS is a system made by the Malaysian government to protect the tafakul (in conjunction with shariah insurance in Indonesia) certificate and insurance policy owners form the default of insurance company that is the member of PIDM. TIPS began to be applied on December 31, 2010, and managed by PIDM (Perbadanan Insurans Deposit Malaysia, 2018). The benefits of TIPS from PIDM for the policyholder and insured are that PIDM will protect against insurance loss if the insurance company has defaulted. The protection provided by the PDIM applies automatically and does not require a registration process.

Moreover, the mechanism of PIDM, especially TIPS, also provides benefit for the Malaysia financial system, including:

1) can increase the public trust in Malaysia financial system and protect the tafakul certificate and insurance policy owners against the loss of benefits;

2) PIDM strengthens and completes the existing regulatory and supervisory framework by providing incentive for good risk management in the financial system;

3) PIDM minimizes the cost for the financial system by finding the lowest cost solution to resolve non-eligible insurance members;

4) PIDM contributes to the stability of the financial system by handling noneligible members of insurance companies immediately (Perbadanan Insurans Deposit Malaysia, 2018).

In the initial PIDM-related regulation, Laws of Malaysia Act 642 Malaysia Deposit Insurance Corporation (Law Of Malaysia Act, 2005), there is an article discussing the scope of protection entitled "scope of coverage." In the article is elaborated that the deposit guaranteed by PIDM include Islamic deposits and 
conventional deposits. The maximum return limit on deposit guaranteed by the PIDM is 60,000 ringgit. In the Act 2005, no article regulates the benefits for the insurance policyholders, either policy based on conventional insurance or shariah insurance.

Meanwhile, in the latest regulation, Law of Malaysia Act 720 Malaysia Deposit Insurance Corporation Act 2011 (Law Of Malaysia Act, 2011) in the part of scope or "scope of coverage" is divided into two major groups, the scope of coverage for deposits and scope of coverage for Tafakul and Insurance Benefits Protection. The scope of coverage for deposits is in accordance with the Act 2005, the type of deposit protected includes the deposit in conventional bank and deposit in Shariah bank. Meanwhile, the scope of coverage for tafakul certificates and insurance policies provides protection for the insurance policyholder or insured, including: family takaful; general takaful; life insurance; and general insurance.

\section{b. Korea Deposit Insurance Corporation (KDIC)}

KDIC was established on June 1, 1996, after the enactment of the Depositor Protection Act (DIPA) on December 29, 1995. Initially, KDIC was only the deposit insurance in the bank (similar to LPS in Indonesia), while there was a separate institution for the non-bank financial sector. The coverage was initially 20 million KRW per depositor, but the financial instability due to the Asian financial crisis in 1997 led the government to adopt the temporary coverage scheme. DPA was revised at the end of 1997, and hence the insurance fund that was initially separated was then merged into KDIC in April 1998. Currently, KDIC guarantees not only the bank deposit but also the deposit by securities companies, insurance companies, commercial banks, mutual funds, savings banks, and credit unions. This creates a single, comprehensive, and integrated deposit insurance system designed to increase financial stability and ensure public trust in the financial system (KDIC, n.d.).

The transition was carried out to limited coverage of 50 million KRW in 2001. The higher boundary was determined to ensure continued stability in financial markets. Because the system is not insusceptible to moral hazard risk, KDIC monitors the financial and non-financial risks from the insured financial institution carefully. Although only operating for a relatively short time, this system has shown incredible growth and will continually give a positive contribution to financial stability through the implementation of various devices and policies designed to advance the deposit insurance system further (KDIC, n.d.).

Based on the Depositor Protection Act (DPA) No. 5042 of December 29, 1995 , Act as last revised with Depositor Protection Act (DPA) No. 14242 May 29, 2016, stated that the aim of the enactment of Depositor Protection Act (DPA) is to protect the customer deposit funds and maintain the financial stability when the financial institution has default due to bankruptcy and others. In the definition part of the Depositor Protection Act (DPA) of 1995 is stated that the definition of "insured financial institution" is as follows:

1. Banks Banks protected by Depositor Protection Act (DPA) include The Korea Development Bank, The Industrial Bank of Korea, The NH Bank, Suhyup Bank, and foreign-owned branch or representative banks in South Korea;

2. Institutions engaged in the capital market ; It includes the securities trading intermediaries (broker), securities traders (dealer), and securities companies;

3. Insurance companies. 
Depositor Protection Act (DPA) also explains the definition of "deposits" or insured deposits. Deposits include money deposited in financial institutions and insurance premiums. KDIC adopts the ex-ante funding system. International Association of Insurance Supervisors (IAIS) explains two funding forms of the policyholder protection scheme in the countries as explained by IAIS, which is ex-ante funding and ex-post funding. IAIS defines ex-ante as "...With ex-ante funding arrangements, the insurance company pays the appraisal to collect and maintain the fund used if the insurance company has defaulted. With this method, the fund can be collected slowly" and define ex-post as "With the ex-post funding arrangements, the insurance company pays the appraisal after it has defaulted. With this method, the insurance company has access to funds until levies are required (IAIS, 2013) The funding of policyholder protection scheme in South Korea through KDIC is ex-antebased. Besides, on an ex-ante basis, South Korea requires non-life insurance companies to guarantee payment of the claim to the third parties connected with the compulsory insurance contract, such as auto insurance and pollution liability insurance, which is issued by the non-life insurance companies that have defaulted.

The policyholder protection scheme of South Korea through KDIC can obtain the additional fund through the issuance of bonds and loans if needed to solve insurance company problems that have defaulted and obtain funds from several entities, including the government and Bank of South Korea (IAIS, 2013). The policyholder protection scheme in South Korea can provide financial support in solving the life and non-life insurances.

\section{Conclusion}

Policyholder protection scheme mandated by Insurance Law should have been established at least 3 (three) years since the enactment of Insurance Law, no later than October 17, 2017. Currently, there is no legal protection for DIC if DIC wants to expand its functions as policy insurance. This is because the scope of duties and authorities of DIC does not cover policy, and hence it is necessary to revise the DIC Law to expand the functions. The merger of LPP and DIC is also found in other countries as Malaysia Deposit Insurance Corporation (PIDM), with Tafakul \& Insurance Benefits Protection, and South Korea through Korea Deposit Insurance Corporation (KDIC).

\section{References}

Ali, H. (1993). Pengantar Asuransi. Jakarta: Bumi Aksara.

Hartono, S. (1992). Hukum Asuransi dan Perusahaan Asuransi. Jakarta: Sinar Grafika.

Hukum Online. (2017). Lembaga Penjamin Polis di Harapkan Segera Terbentuk.

IAIS. (2013). International Association of Insurance Supervisors (p. 13). p. 13.

KDIC. (n.d.). The Structure of Deposit Insurance. Seoul: Korea Deposite Insurance Corporation.

Law Of Malaysia Act. Malaysia Deposit Insurance Corporation Act 2005. , (2005).

Law Of Malaysia Act. (2011). Malaysia Deposit insurance Corporation Act 2011.

Negara Kesatuan Republik Indonesia. Kitab Undang-Undang Hukum Perdata. 
Negara Kesatuan Republik Indonesia. Penetapan Peraturan Pemerintah Pengganti Undang-Undang Nomor 3 Tahun 2008 Tentang Perubahan Atas Undang-Undang Nomor 24 Tahun 2004 Tentang Lembaga Penjamin Simpanan Menjadi UndangUndang. , (2008).

Negara Kesatuan Republik Indonesia. Undang-Undang Nomor 40 Tahun 2014 tentang Perasuransian. , (2014).

Negara Kesatuan Republik Indonesia. Undang-Undang tentang Pencegahan dan Penanganan Krisis Sistem Keuangan., (2016).

Norma, S. (2012). An Analysis On The Efficiency Of Takaful And Insurance Companies In Malaysia: A Non-Parametric Approach. Jurnal Review Of Integrative Business \& Economics.

OECD. (2010). The Growing Importance Of Takaful Insurance. Asia Regional Seminar Organized By OECD And Bank Negara Malaysia Under The Sponsorship Of The Government Of Japan. Kuala Lumpur.

Perbadanan Insurans Deposit Malaysia. (2018). Mandate.

Rossiana, G. (2014). Lembaga Penjamin Polis Tak Miliki Fungsi Bailout.

Salam, S. (2017). Analisis Perjanjian Kerjasama Dan Pola Perbandingan Penyelesaian Sengketadi Luar Pengadilan. Jurnal Hukum Volkgeist, 2(1), 86.

Sendra, K. (2009). Klaim Asuransi: Gampang! (p. 50). p. 50. Jakarta: Badan Mediasi dan Arbitrase Asuransi Indonesia.

Sumarni, \& Tayib, A. (2019). Polis Asuransi Jiwa Sebagai Jaminan untuk Mendapatkan Kredit pada Perusahaan Asuransi. Unizar Law Review. 